Proceedings

\title{
Terpenic Compounds in Chilean Species of the Genus Blechnum (Pteridophyta: Blechnaceae) with Neuroprotective Potential $^{\dagger}$
}

\author{
Mathias Flores-González, Alfredo Torres-Benítez * and Mario Simirgiotis
}

Citation: Flores-González, M.; Torres-Benítez, A.; Simirgiotis, M Terpenic Compounds in Chilean Species of the Genus Blechnum (Pteridophyta: Blechnaceae) with Neuroprotective Potential. Proceedings 2021, 71, 2. https://doi.org/doi:10.3390/IECBS08535

Published: 23 November 2020

Publisher's Note: MDPI stays neutral with regard to jurisdictional claims in published maps and institutional affiliations.

Copyright: (ㄷ 2020 by the authors. Licensee MDPI, Basel, Switzerland. This article is an open access article distributed under the terms and conditions of the Creative Commons Attribution (CC BY) license (http://creativecommons.org/licenses/by/4.0/)
Instituto de Farmacia, Facultad de Ciencias, Universidad Austral de Chile, 5090000 Valdivia, Chile; mathy.power.96@gmail.com (M.F.-G.); mario.simirgiotis@gmail.com (M.S.)

* Correspondence: aljotobe19@hotmail.com; Tel.: +57-9-9054-9002

† Presented at the 1st International Electronic Conference on Brain Sciences, 10-25 November 2020; Available online: https://sciforum.net/conference/IECBS.

\begin{abstract}
The genus Blechnum L. includes a large variety of species native to central and southern continental Chile: B. arcuatum, B. asperum, B. blechnoides, B. chilense, B. corralense, B hastatum, B. magellanicum, B. microphyllum, B. mochaenum and B. penna-marina, containing compounds such as flavonols, hydroxycinnamic acids, lignans, and phytoecdysteroids. In this examination, terpenic compounds of the phytoecdysone type with pharmacological potential on the central nervous system are detailed. These compounds are characterized by a C27, C28 or C29 structure that possesses a 14alpha-hydroxy-7-en-6-one chromophore and an A/B-cis (5beta-H) ring fusion that can be extracted from the plant with organic solvents, such as hexane, dichloromethane, ethyl acetate, methanol, and ethanol, is concentrated in a reduced pressure rotary evaporator and are identified by gas chromatography coupled to a mass spectrometry detector (GC-MS) or a tandem ionization electrospray network detector UHPLC-DAD-ESI-MS/MS. Phytoecdysteroids applied in vitro and in vivo models of neurodegenerative diseases such as Parkinson's and Alzheimer's at concentrations between 100 and $500 \mu \mathrm{g} / \mathrm{mL}$, can modulate the enzymatic inhibition of monoamine oxidases (MAO-A and MAO$\mathrm{B})$ and cholinesterases (AChE and BChE), with zero toxicity effects and satisfactory results in cell viability.
\end{abstract}

Keywords: terpenic; Blechnum; Chile; neuroprotective potential

\section{Introduction}

The pteridophytes are a group of plants within which specifically, the ferns are a type of plants with a rich variety of phytochemical compounds, existing from alkaloids, flavonoids, polyphenols, steroids, and terpenes, which in turn can mean a potential pharmacological use for some species of ferns [1].

The products of vegetable origin participate in a great percentage of the care of human health. Among these products, we can name compounds of the terpenes group that comprise a wide range, including hemiterpenes, C10 monoterpenes, C15 sesquiterpenes, C20 diterpenes, C25 sesterterpenes, and C30 triterpenes. Many of these compounds and their derivatives have a wide range of biological activity [2].

As for ferns, genera such as Blechnum have species where the presence of multiple terpenic compounds has been confirmed, through studies conducted over time. As a result of these findings, it has been possible to identify several terpenic compounds in species of the genus Blechnum, being able to name among those that were expressed in greater measure the neofitadiene, isofitol, and phytol. The applications for medicine that extracts containing these types of terpenic compounds may have are wide, given the range of biological activity that these phytochemicals present [3]. 


\section{Methods}

A literature search was conducted in July 2020 in the PubMed, Scopus, and ScienceDirect databases using the descriptors: Blechnum, terpenes, neurodegenerative diseases, neuroprotection. We also identified references from relevant review articles, and others registered in the section of similar articles in PubMed.

\section{Results and Discussion}

In fern species of the genus Blechnum, phytoecdysteroids have been isolated as neophytadiene (1), isophytol (2), phytol (3), ecdysone (4), ponasterone (5), shidasterone (6), $\beta$ sitosterol (7), and 2-deoxycrusteecdysone (8) [3,4]; however, compounds 1, 2 and 3 (Figure 1) report higher abundance and biological activity [5-7] in comparison with other compounds (Figure 2).

(1)<smiles>CCC(=O)CCCC(=O)CCCC(C)CCCC(C)CCCC(C)C</smiles>

(2)<smiles>C=CC(C)(C)CCCC(C)CCCC(C)CCCC(C)C</smiles>

(3)<smiles>CC/C=C(\C)CCC[C@H](C)CCC[C@H](C)CCCC(C)C</smiles>

Figure 1. Chemical structure of neophytadiene (1), isophytol (2) and phytol (3).

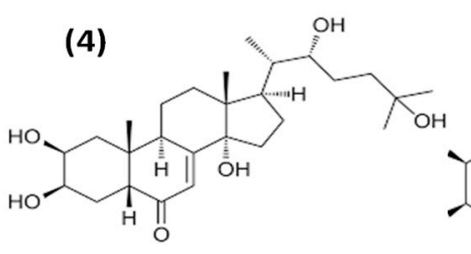<smiles>CC(C)CCCC(O)C(C)(C)C1CCC2C3=CC(=O)C4CCCC3(C)CCCC2C41C</smiles>

(6)<smiles>CC12CCC(O1)C2(C)C</smiles>

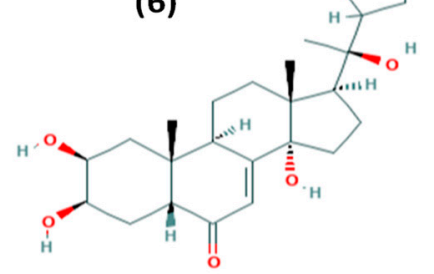

(7)

(8)<smiles>CCC(CCC(C)(C)C12CCC3C4C=C5CC(O)CCC5(C)C4CCC3(C)C1CC2)C(C)C</smiles>

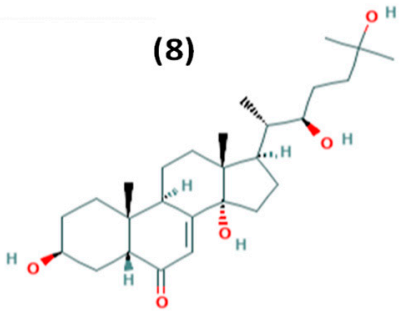

Figure 2. Chemical structure of ecdysone (4), ponasterone (5), shidasterone (6), $\beta$-sitosterol (7), and 2-deoxycrusteecdysone (8).

In Chile, species of the genus Blechnum such as $B$. arcuatum, $B$. asperum, B. blechnoides, B. chilense, B. corralense, B hastatum, B. magellanicum, B. microphyllum, B. mochaenum, and B. 
penna-marina, constitute a promising source for the study and obtention of these compounds, to extend the effects in therapeutic targets of the most prevalent and incidental neurodegenerative diseases: Alzheimer's, Parkinson's, Huntington's, and multiple sclerosis.

Gas chromatography techniques coupled to a mass spectrometry detector (GC-MS) or a tandem ionization electrospray network detector UHPLC-DAD-ESI-MS/MS, constitute the robust techniques for the identification and quantification of secondary metabolites present in complex extracts from ferns and related plants, made from different polar and non-polar organic solvents $[3,8]$.

There is evidence for the neuroprotective activity of phytoecdysteroids isolated from species of the genus Blechnum, based on the inhibition of the enzyme monoamine oxidase in its isoforms MAO-A and MAO-B, with greater effectiveness on MAO-A according to the IC 50 values obtained in the different concentrations of the pure extracts and/or fractions. Moreover, the beneficial effects of these extracts are expressed in the inhibition activity on the enzymes acetylcholinesterase (AChE) and butyrylcholinesterase (BChE) with differential results in the $\mathrm{IC}_{50}$ values, and superior to other antioxidant potential and enzymatic inhibition assays $[9,10]$.

\section{Conclusions}

The species of the genus Blechnum present in Chile contain bioactive compounds of the phytoecdysteroids type that can be extracted with various organic solvents such as hexane, dichloromethane, methanol, and ethanol with efficient performance results. Moreover, the identification of the chemical composition by gas chromatography methods coupled to a mass spectrometry detector (GC-MS) or a tandem ionization electrospray network detector UHPLC-DAD-ESI-MS/MS, is appropriate for the measurement and analysis of the abundance and heterogeneity of the compounds present in the extracts.

Extract fractions of species of the genus Blechnum show potential biological activity against different therapeutic targets of neurodegenerative diseases, especially in Parkinson's disease, with the inhibition of the enzyme monoamine oxidase in its MAO-A isoform, and in a complementary way, with the suppression of cholinesterase enzymes (AChE and BChE).

Author Contributions: All authors contributed equally to this work. All authors discussed the results and implications, and commented on the manuscript at all stages. A.T.-B. and M.F.-G. wrote the paper. All authors have read and agreed to the published version of the manuscript.

Funding: This research was funded by CONICYT PFCHA/National Doctorate Scholarship/49252020 (A.T.-B.).

Acknowledgments: To the laboratory of Natural Products of the Institute of Pharmacy of the Universidad Austral de Chile.

Conflicts of Interest: The authors declare no conflict of interest.

\section{References}

1. Cao, H.; Chai, T.T.; Wang, X.; Morais-Braga, M.F.B.; Yang, J.H.; Wong, F.C.; Wang, R.; Yao, H.; Cao, J.; Burlando, B.; et al. Phytochemicals from fern species: Potential for medicine applications. Phytochem. Rev. 2017, 16, 379-440.

2. Wang, G.; Tang, W.; Bidigare, R.R. Terpenoids as therapeutic drugs and pharmaceutical agents. In Natural Products; Zhang, L., Demain, A.L., Eds.; Human Press: Totowa, NJ, USA, 2005; pp. 197-227.

3. Andrade, J.M.D.M.; Maurmann, N.; Pranke, P.; Turatti, I.C.C.; Lopes, N.P.; Henriques, A.T. Identification of compounds from non-polar fractions of Blechnum spp. and a multitarget approach involving enzymatic modulation and oxidative stress. J. Pharm. Pharmacol. 2016, 69, 89-98.

4. Hincapié, C.; Monsalve, Z.; Parada, K.; Lamilla, C.; Alarcón, J.; Céspedes, C.; Seigler, D. Insect growth regulatory activity of Blechnum chilense. Nat. Prod. Commun. 2011, 6, 1085-1088.

5. Zapata, N.; Ceballos, R.; Céspedes, C.; Alarcón, J.; Leyton, A. Insecticidal activity and growth regulatory of Blechnum chilense (Blechnaceae) and Condalia microphylla Cav. (Rhamnaceae) extracts, on larvae of Galleria mellonella (L.) (Lepidoptera: Pyralidae). Bol. Latinoam. Caribe Plantas Med. Aromát. 2016, 15, 77-87. 
6. Hincapié, C.; Monsalve, Z.; Parada, K.; Lamilla, C.; Alarcón, J.; Céspedes, C. Mite growth regulatory activity of Blechnum chilense (Kaulf.) Mett. Planta Medica 2011, 77, SL54.

7. Alarcón, J. Chemical and biological study of Chilean ferns: Genus Adiantum, Blechnum and Cheilantes. Bol. Latinoam. Caribe Plantas Med. Aromát. 2009, 8, 548.

8. Thiem, B.; Kikowska, M.; Malinski, M.; Kruszka, D.; Napierala, M.; Florek, E. Ecdysteroids: Production in plant in vitro cultures. Phytochem. Rev. 2017, 16, 603-622.

9. Van Der Schyf, C.J.; Geldenhuys, W.J. Monoamine oxidase and their inhibitors multimodal drugs and their future for Alzheimer's and Parkinson's disease. Int. Rev. Neurobiol. 2011, 100, 107-125.

10. Andrade, J.M.D.M.; Biegelmeyer, R.; Dresh, R.R.; Maurmann, N.; Pranke, P.; Henriques, A. In vitro antioxidant and enzymatic approaches to evaluate neuroprotector potential of Blechnum extracts without cytotoxicity to human stem cells. Pharmacogn. Mag. 2016, 12, 171-177. 